УДК 371.398: 374.7+004

Скрипка Ганна Володимирівна

кандидат педагогічних наук, старший викладач кафедри теорії і методики середньої освіти Комунальний заклад «Кіровоградський обласний інститут післядипломної педагогічної освіти імені Василя Сухомлинського», м. Кіровоград, Україна

annaskripka3@gmail.com

\title{
ВНУТРІШНЯ ОПТИМІЗАЦІЯ УЧИТЕЛЬСЬКОГО БЛОГУ, СТВОРЕНОГО НА ВLOGSPOT.COM
}

\begin{abstract}
Анотація. У статті наведені рекомендації для вчителів-предметників щодо внутрішньої оптимізації блогу, створеного засобами ресурсу blogspot.com: оптимізація URL-адреси сторінок блогу; коректне формулювання заголовків дописів чи сторінок; вилучення повторюваного контенту; додавання метатегів; використання тегів заголовків безпосередньо в дописах блогу. Практичне використання зазначених прийомів внутрішньої оптимізації показало, що учительський блог потрапляє на перші місця пошукових серверів, а, отже, набуває своєї популярності й дає можливість збільшити відвідуваність блогу. Зазначена проблема набуває популярності і $є$ значущою, оскільки все більша кількість педагогів створюють свої блоги і використовують їх для спілкування 3 іншими учасниками навчально-виховного процесу.
\end{abstract}

Ключові слова: СЕО-оптимізація; блог учителя; популяризація блогу; внутрішня оптимізація блогу.

\section{1. ВСТУП}

Постановка проблеми. Останнім часом усе більше педагогів створюють свої блоги, з допомогою яких вони спілкуються $з$ учнями, батьками, а також колегами. Такий освітній Інтернет-ресурс дозволяє демонструвати свої досягнення, розміщувати актуальну інформацію, реалізувати обмін досвідом, консультації та багато інших [5]. Саме професійне спілкування з педагогами, i, як наслідок, розширення інформаційного освітнього середовища, дозволяє вчителеві ефективно працювати в сучасному інформаційному суспільстві та забезпечувати високу якість навчання.

До переваг блогів відносять відкритість інформаційного наповнення для всіх учасників, оперативність розміщення інформації і доступу до неї, незалежність від індивідуального графіка відвідування учасниками блогу, інтерактивність [2].

Нині необхідною умовою участі педагога в конкурсі «Учитель року» є створення і ведення блогу, до того ж кількість конкурсів блогів освітян 3 кожним роком невпинно зростає. Усе це призводить до того, що створення вчительського блогу є необхідністю сучасного педагога й українські вчителі активно працюють у цьому напрямі. Наразі, найчастіше читачами вчительських блогів є вчителі-колеги 3 одного міста (району, області), які знайомі очно з автором блогу, або ж знайомі в соціальних мережах. Натомість нині існують способи оптимізації блогів, які дозволяють пошуковим серверам знаходити потрібний блог першим.

Отже, постає необхідність ознайомлення вчителів зі способами оптимізації блогів, створених з допомогою сервісу blogger.

Аналіз останніх досліджень і публікацій. У наукових дослідженнях останніх років теоретичні аспекти використання інформаційно-комунікаційних технологій розв’язують такі науковці, як І. Богданова, С. Буртовий, В. Вембер, С. Литвинова, Л. Панченко, О. Глазунова, Н. Морзе, О. Рєзіна, використання соціальних сервісів Н. Балик, Н. Дементієвська, А. Забарна, О. Лялик, I. Сокол, Н. Сороко, питання 
розробки i наповнення учительського блогу - С. Лабудько, Н. Вінницька, С. Стельмащук, В. Осадчий, I. Табарчук та інші.

Позаяк грунтовний аналіз науково-педагогічних джерел свідчить, що практичний аспект оптимізації учительського блогу не був предметом окремого дослідження i висвітлений недостатньо.

Актуальність проблеми оптимізації учительського блогу очевидна, тому вона потребує спеціального дослідження. Необхідно з'ясувати способи оптимізації блогу, створеного з допомогою сервісу blogger.

Метою статті $\epsilon$ висвітлення способів оптимізації блогу вчителя, створеного 3 допомогою сервісу blogger.

\section{2. РЕЗУЛЬТАТИ ДОСЛІДЖЕННЯ}

Сучасні інформаційно-комунікаційні технології забезпечують можливість вчителів співпрацювати 3 колегами, дізнаватися про нові ресурси й можливості впровадження їх у навчально-виховний процес і, як наслідок, сприяти підвищенню якості шкільної освіти. Одним із способів такої комунікації є створення учительського блогу, його популяризація і використання для співпраці і спілкування 3 колегами, учнями й батьками. Блоги виконують такі функції [6, с. 75]:

1) комунікативну;

2) самопрезентації;

3) розваги;

4) групування й утримання соціальних зв'язків;

5) мемуарів;

6) саморозвитку або рефлексії;

7) психотерапевтичні.

У навчально-виховному процесі виокремлюють такі способи використання блогів [7]: а) фіксування певних подій студентського життя й коментарі до них з боку майбутніх філологів; б) обговорення навчальних тем; в) обговорення прочитаних книжок, письменників, жанрів, стилів тощо; г) обговорення країнознавчих реалій; г) використання як платформи / відправної точки у вивченні певних мовних тем, коли майбутні філологи, відвідуючи блог, отримують доступ до інших веб-ресурсів, корисних або необхідних у вивченні цієї теми чи питання.

3 метою вивчення іноземних мов Ю. Яценко пропонує створювати блог учителя (tutor blog), блог класу (class blog) або навчальний блог (learner blog) [8], кожен з яких має своє призначення, авторів та по-своєму ефективний у процесі навчання.

Проте як можна популяризувати свій блог, аби пошукові сервери першими знаходили його і якомога більше користувачів його відвідували? Розглянемо основні принципи і способи оптимізації блогу вчителя.

Пошукова оптимізація сайту (блогу) або ж SEO (англ. search engine optimization) - процес коректування HTML-коду, текстового наповнення (контенту), структури сайту, контроль зовнішніх чинників для відповідності вимогам алгоритму пошукових систем, 3 метою підняття позиції сайту в результатах пошуку в цих системах за певними запитами користувачів. Технологія пошукової оптимізації дозволяє залучати в блог більше відвідувачів і пропонувати свій контент зацікавленій у ньому аудиторії [3]. Чим вищою є позиція сайту в результатах пошуку, тим більша ймовірність, що відвідувач перейде на нього з пошукових систем, оскільки, зазвичай, близько $100 \%$ користувачів заходить за першими трьома посиланнями пошукової видачі, далі тенденція до зменшення - до десятого посилання першої сторінки видачі дістаються 20-50 \% користувачів [4]. 
Існує декілька способів оптимізувати свій ресурс.

$>$ Зовнішня оптимізація - просування блогу чи сайту з допомогою зовнішніх ресурсів.

> Внутрішня оптимізація - оптимізація текстів і сторінок ресурсу.

Кожен із представлених способів може бути наступних видів:

$\checkmark$ Біла оптимізація (удосконалення коду, тексту та інших параметрів сайту під алгоритми пошукових систем).

$\checkmark$ Сіра оптимізація (штучна накрутка лічильників; додавання занадто великої кількості ключових слів, що ускладнює сприйняття інформації, розміщеної на сторінці). Варто зазначити, що за такої оптимізації можливе блокування сайту.

$\checkmark$ Чорна оптимізація (застосування заборонених і недобросовісних методів для підлаштування коду, тексту чи інших параметрів сайту під алгоритми пошукових систем).

Розглянемо детальніше прийоми білої внутрішньої оптимізації учительського блогу, створеного з допомогою сервісу blogger. Серед них виділяють оптимізацію URLадреси сторінок блогу, коректне формулювання заголовків дописів чи сторінок, вилучення повторюваного контенту, додавання метатегів та тегів заголовків.

1. Структура URL-адреси сторінки (допису) блогу.

Пошукові сервери в першу чергу знаходять ті сторінки, у яких URL-адреса містить слова $з$ пошукових запитів користувачів. Тому, якщо автор блогу бажає, аби його сторінку пошукові сервери знаходили першою, в адресу сторінки або допису слід включити слова, найбільш популярні серед пошукових запитів. Натомість blogger, як i більшість ресурсів для створення блогів, генерує адреси сторінок, які не містять потрібні ключові слова. Це пов'язане з тим, що наші вчителі створюють сторінки, заголовки яких мають текст, написаний українською мовою, a blogger формує адресу відповідно до назви лише в тому випадку, якщо заголовок допису або сторінки написаний латиницею. Отже, для того, щоб створити сторінку з адресою, яку будуть знаходити пошукові сервери першою, слід створити сторінку із заголовком, текст якого сформований шляхом транслітерації. Наприклад, користувачу потрібно створити сторінку, в адресі якої має міститися текст «хмарні ресурси». Транслітерувати текст можна 3 допомогою онлайнових ресурсів http://www.slovnyk.ua/services/translit.php, http://translit.kh.ua/, http://ua.translit.cc/, http://tran.comze.com/tcyr.html та інших. Шляхом транслітерації отримується текст «khmarni resursy», який необхідно вписати у заголовок нової сторінки блогу (рис. 1).

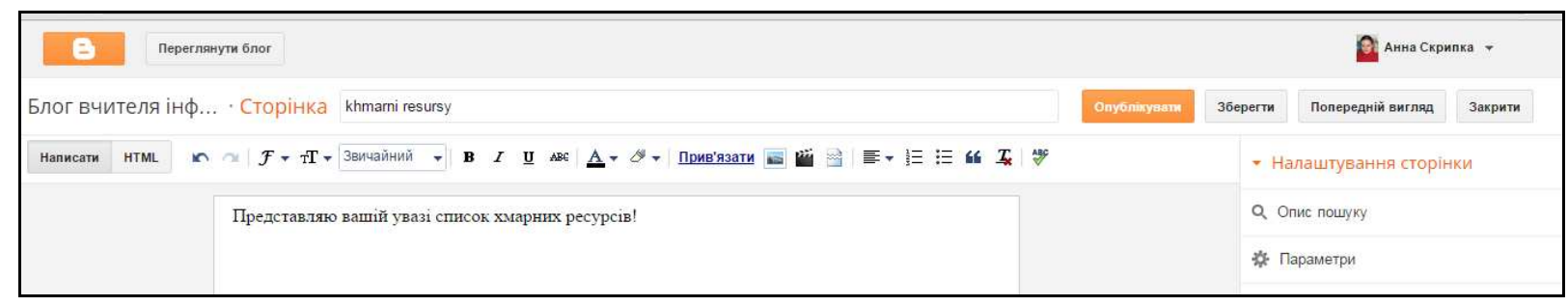

Рис. 1. Створення нової сторінки блогу

У результаті отримаємо сторінку, адреса якої матиме такий вигляд: http://skrypkahanna111.blogspot.com/p/khmarni-resursy.html.

Наступним кроком буде зміна заголовку сторінки на ту, яку зручно буде читати користувачам (це «Хмарні ресурси» замість «khmarni resursy») і подальша публікація сторінки або допису (рис. 2). 


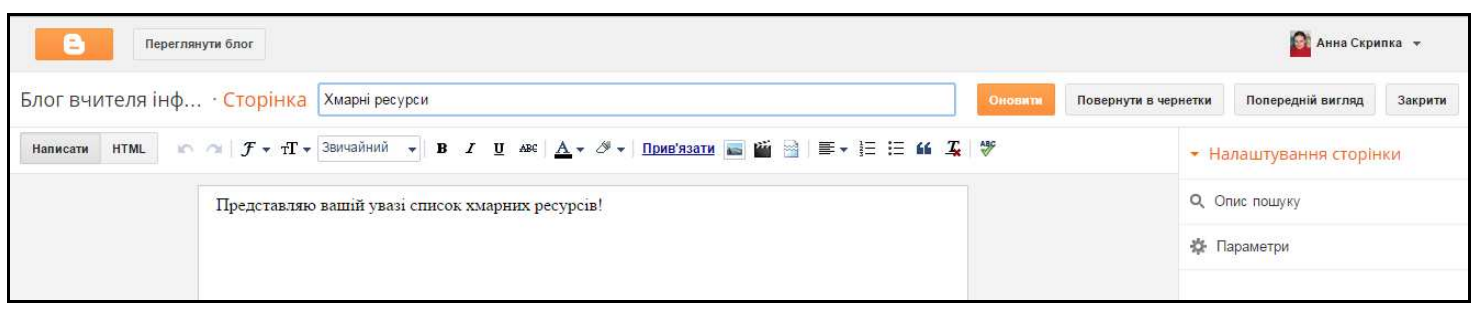

Рис. 2. Зміна заголовку сторінки блогу

\section{2. Правильне формулювання заголовків сторінок (дописів) блогу.}

Якщо автор допису бажає, аби сторінки його блогу знаходили пошукові сервери, то у заголовках сторінок або дописів повинні обов' язково міститися ключові слова, які пишуть користувачі для пошуку потрібної інформації. Так, у разі створення автором блогу сторінки 3 назвою «Корисні ресурси», вона навряд чи буде першою серед результатів пошуку. Тут слід подумати над тим, які ключові слова автор писав сам, шукаючи ці «корисні ресурси»? Що шукають колеги чи з яких питань вони хотіли 63 вами поспілкуватися? Саме ці слова й потрібно використовувати для створення заголовків дописів або сторінок учительського блогу. Для підбору ключових слів використовують онлайнові ресурси: планувальник ключових слів (https://adwords.google.com/), Google Тренди (http://www.google.com/trends), Яндекс. Вордстат https://wordstat.yandex.ru, Soovle (http://www.soovle.com) та багато інших.

\section{3. Повторюваний контент.}

Жодна 3 пошукових систем не полюбляє повторюваного контенту, проте додавання міток до дописів (сторінок) на блозі, додавання дописів в архів та деякі інші дії на блозі можуть утворити дубляж інформації, i, як наслідок, призвести до потрапляння блогу в Google supplemental index (списку ресурсів 3 неякісним контентом), результатом чого стає пониження ресурсу в результатах пошуку. Наразі, кожен сайт чи блог має свій файл robots.txt, який містить важливу інформацію для пошукових систем. Зокрема, перш ніж приступити до проходження по сторінках конкретного сайту чи блогу, будь-який робот переглядає саме цей файл. Завдяки існуванню файлу robots.txt сканування сайту проводиться більш ефективно і якісно. Файл дозволяє роботам негайно переходити до конкретної, дійсно суттєвої інформації, яка розташована на сторінках ресурсу.

Для того, аби вберегтися від дублювання інформації, необхідно відкрити «Налаштування пошуку» блогу, а далі у вікні «Спеціальний файл robots.txt» натиснути кнопку «Редагувати» і вставити наступний код:

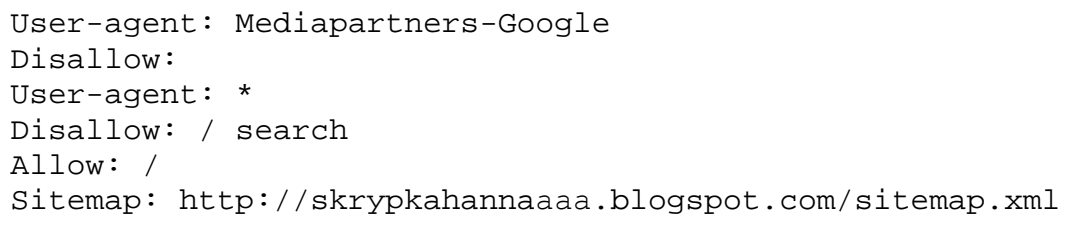

Замість виділеного червоним кольором посилання слід додати посилання на власний блог. У представленому коді директива User-agent: Mediapartners-Google визначає доступ пошукового робота Google, a User-agent: * всіх пошукових роботів (Google, Yahoo, Bing, Yandex та ін.). Директива Disallow: / забороняє пошуковим роботам сканувати будь-які конкретні сторінки або каталоги, які $є$ на блозі (це й можуть бути сторінки з повторюваним контентом). Директиву Allow використовують для того, аби дозволити доступ роботу до деяких частин сайту (блогу) або сайту повністю. 
Також слід налаштувати «Спеціальний тег заголовка 3 параметром robots» так, як вказано на рис.3:

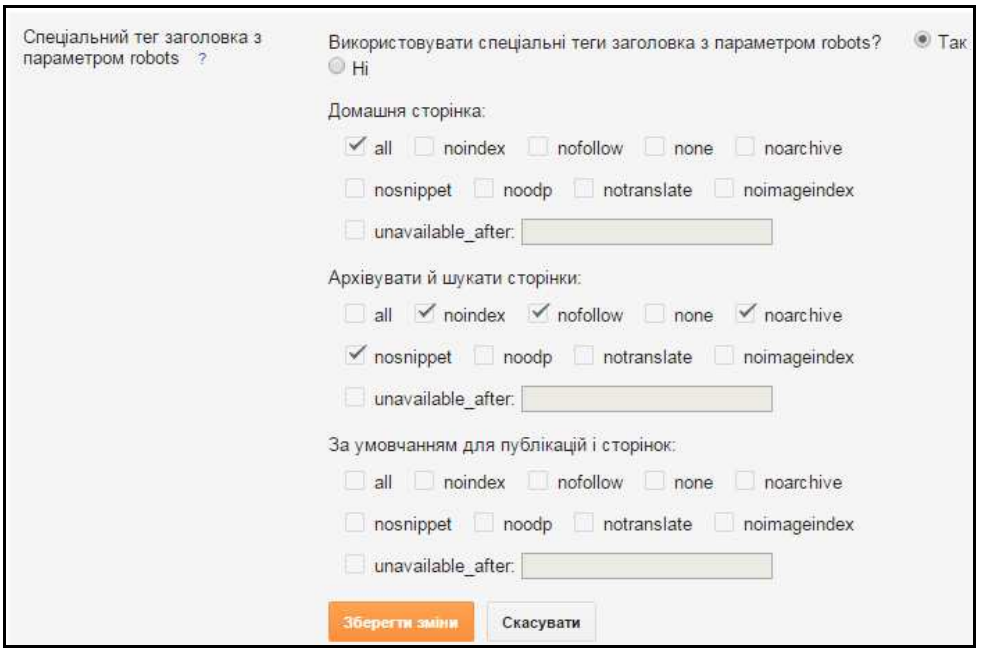

Рис. 3. Налаштування спеціального тегу заголовка з параметром robots

\section{4. Метатеги.}

Використання метатегів допоможе вивести блог на перші позиції пошукових серверів. Для того, аби додати метатеги до блогу, створеного на blogger, необхідно відкрити вікно «Налаштування» блогу i натиснути посилання «Редагування» та додати опис блогу (рис. 4).

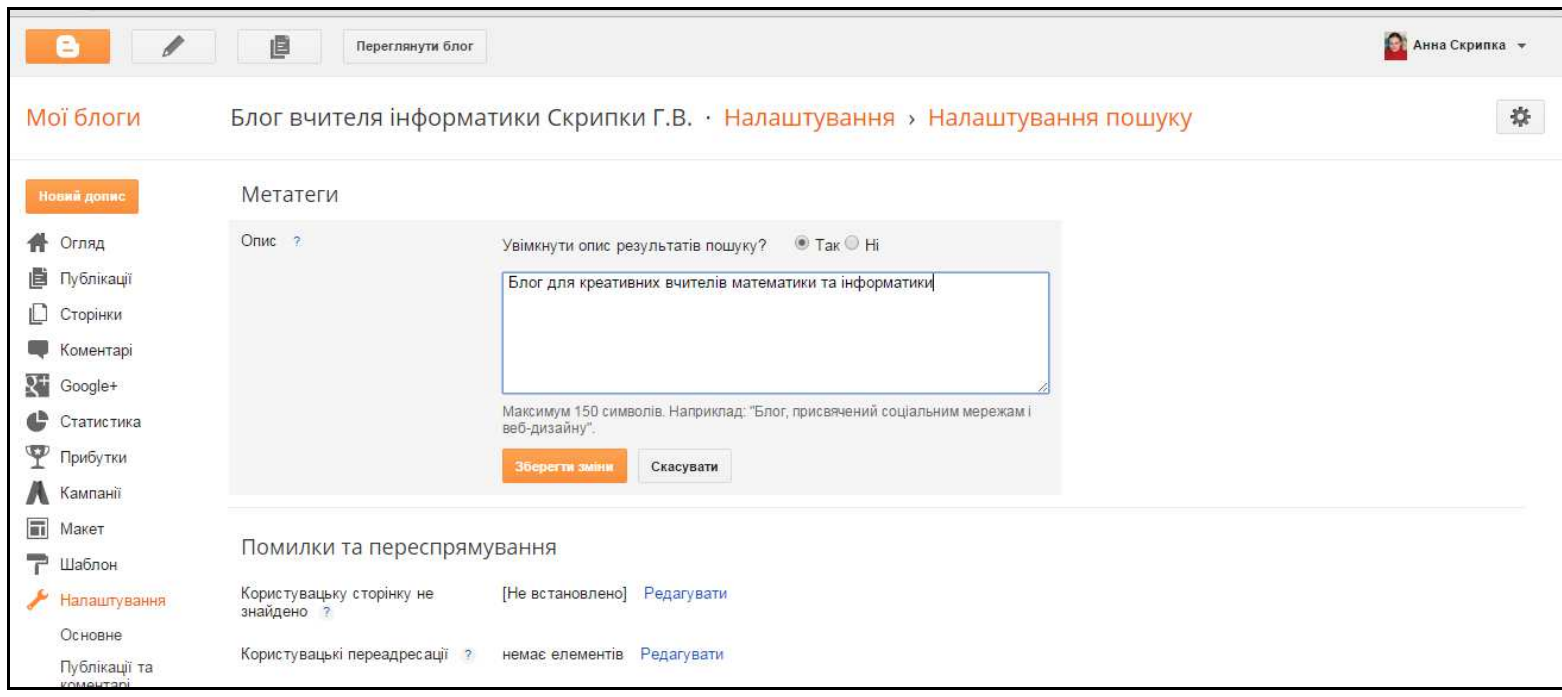

Рис. 4. Додавання опису блогу

Для того, щоб додати метатеги до окремих сторінок блогу, необхідно відкрити на панелі налаштувань дописів (сторінок) опцію «Опис пошуку» і додати ключові слова, за якими буде здійснюватися пошук цієї сторінки (рис. 5). 


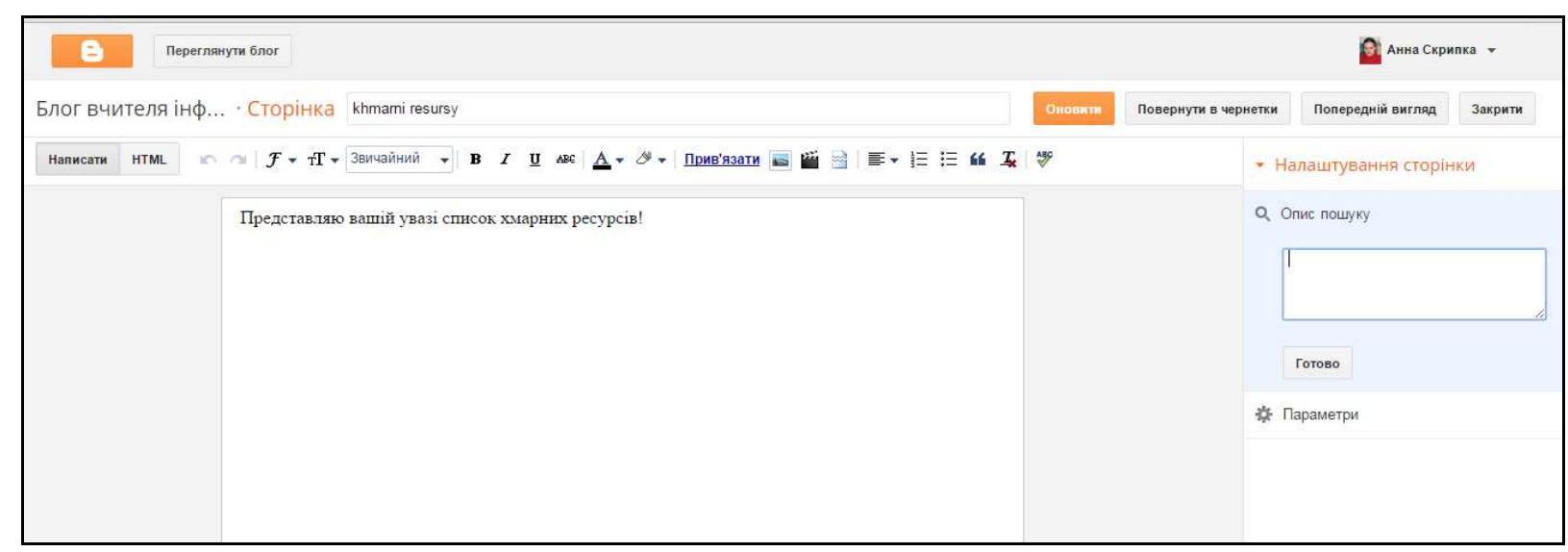

Рис.5. Додавання опису до сторінки блогу

\section{5. Теги заголовків.}

Вдалі заголовки дають можливість зрозуміти, про що йде мова в тексті. Попри це, за ним пошукові системи визначають зміст записів у блозі. У Blogger можна позначати частину тексту як заголовок, у результаті чого пошукова система використовує його як коротку анотацію викладеного в повідомленні.

Існує кілька тегів заголовків, які можна додати в текст. Вони потрібні для того, щоб задати ієрархію заголовків і розмір їх шрифту. Приклад списку заголовків (від більшого до меншого): h2 ... h4. Щоб позначити текст як заголовок, слід виділити його в редакторі повідомлень і вибрати на панелі інструментів параметр «Заголовок» $(<\mathrm{h} 2>)$, «Підзаголовок» (<h3>) або «Другий підзаголовок» (<h4>) (рис. 6).

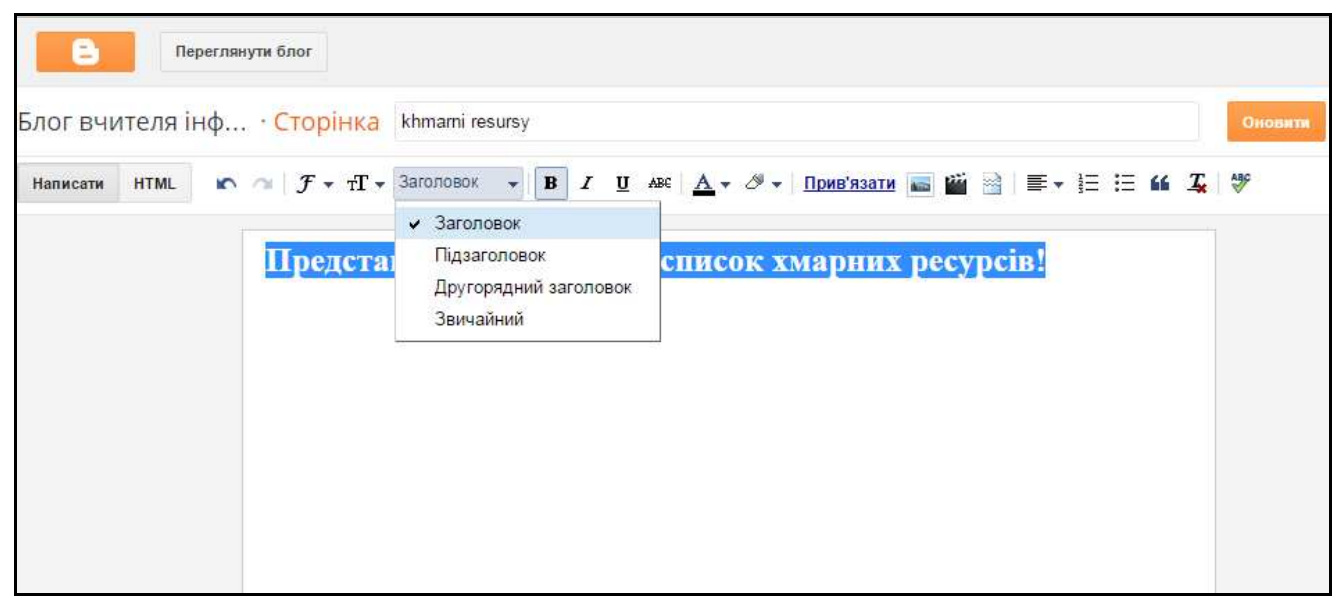

Рис. 6. Перетворення тексту допису на заголовок

Наостанок хочеться додати, що учительський блог має містити унікальні тексти. Лише в цьому разі він може претендувати на перші позиції пошукових систем. Нехай це будуть невеликі дописи (сторінки), але написані вони мають бути від душі, самостійно, з власного досвіду.

\section{3. ВИСНОВКИ ТА ПЕРСПЕКТИВИ ПОДАЛЬШИХ ДОСЛІДЖЕНЬ}

Кількість учительських блогів стрімко збільшується, проте їх читачами залишаються люди з безпосереднього оточення власника блогу. Прийоми внутрішньої 
оптимізації $є$ не надто складними для вчителя-предметника із середнім чи достатнім рівнем компетентностей у питаннях інформаційно-комунікаційних технологій, i дозволяють вивести ресурс на перші місця пошукових серверів, й отже, популяризувати блог і залучити більшу кількість читачів. Ми виокремили такі способи внутрішньої оптимізації учительського блогу, створеного з допомогою pecypcy Blogger:

- оптимізація URL-адреси сторінок блогу;

- коректне формулювання заголовків дописів чи сторінок;

- вилучення повторюваного контенту;

- додавання метатегів;

- використання тегів заголовків безпосередньо в дописах блогу.

Перспективними напрямами подальших досліджень можна вважати питання зовнішньої оптимізації учительських блогів, а також прийомів СЕО-оптимізації блогів, створених з допомогою інших ресурсів.

\section{СПИСОК ВИКОРИСТАНИХ ДЖЕРЕЛ}

1. Балик Н. Р., Лялик О. О. Активне навчання з використанням технологій Веб 2.0: Навч. пос. Тернопіль : Навчальна книга - Богдан, 2009. - 88 с.

2. Вінницька Н. М., Стельмащук С. А. Можливості використання освітніх блогів. Технологія веб 2.0. // Інформатика в школі : Видавнича група «Основа». - 2012. - № 7 (43). - 80 с.

3. Дементієвська Н. П. Соціальні сервіси Веб 2.0 як засіб інтерактивного навчання. [Електронний ресурс] / Н. П. Дементієвська. http://lib.iitta.gov.ua/652/1/\%D0\%A1\%D0\%BE\%D1\%86\%D1\%96\%D0\%B0\%D0\%BB\%D1\%8C\%D0\% BD\%D1\%96_\%D1\%81\%D0\%B5\%D1\%80\%D0\%B2\%D1\%96\%D1\%81\%D0\%B8_\%D0\%92\%D0\%B5 \%D0\%B1_2.0_1_\%5BCompatibility_Mode\%5D.pdf.

4. Забарна А. П. Використання мережевих щоденників (блогів) у навчально- виховному процесі школи // Інформатика та інформаційні технології в навчальних закладах. - 2008. - №5 (17). - С. 45-49.

5. Лабудько С. П. Блог як сучасний засіб взаємодії вчителів [Електронний ресурс] / С. П. Забудько. Режим доступу : http://conf.vntu.edu.ua/eiron/2013/pdf/18.pdf.

6. Скрипка Г. В. Тренінги за програмою Intel «нноваційна модель Е-навчання «1 учень - 1 комп'ютер» як чинник розвитку ІК-компетентності педагогів / Г. В. Скрипка // Інформатика та інформаційні технології в навчальних закладах. - 2013. - №5 (46). - С. 43-47.

7. Сокол І. М. Технологія ВЕБ 2.0. Сайти, блоги, фотосервіси, карти знань / Сокол І. М. - К. : Шкільний світ, 2011. - 128 с.

8. Сороко Н. В. Використання Веб-технологій у професійній діяльності вчителів філологічної спеціальності [Електронний ресурс] / Н. В. Сороко. - Режим доступу : http://www.irbisnbuv.gov.ua/cgi-

bin/irbis_nbuv/cgiirbis_64.exe?C21COM=2\&I21DBN=UJRN\&P21DBN=UJRN\&IMAGE_FILE_DOW NLOAD=1\&Image_file_name=PDF/komp_2014_1_9.pdf.

9. О Blogger и поисковой оптимизации [Електронний ресурс]. - Режим доступу : https://support.google.com/blogger/answer/2472665?hl=ru.

10. Оптимізація для пошукових систем [Електронний ресурс]. - Режим доступу : http://uk.wikipedia.org/wiki/\%D0\%9E\%D0\%BF\%D1\%82\%D0\%B8\%D0\%BC\%D1\%96\%D0\%B7\%D0 $\%$ B0\%D1\%86\%D1\%96\%D1\%8F_\%D0\%B4\%D0\%BB\%D1\%8F_\%D0\%BF\%D0\%BE\%D1\%88\%D1\%8 3\%D0\%BA\%D0\%BE\%D0\%B2\%D0\%B8\%D1\%85_\%D1\%81\%D0\%B8\%D1\%81\%D1\%82\%D0\%B5\% $\mathrm{D} 0 \% \mathrm{BC}$.

11. Осадчий В. В. Передумови та технології створення освітніх Інтернет-ресурсів / Проблеми інженерно-педагогічної освіти. - 2009.- № 22-23.- С. 162-170.

12. Палкова А. В. Применение сервисов Веб 2.0 в преподавании иностранных языков / А. В. Палкова // Преподавание иностранных языков в мультимедийном пространстве. - Тверь : Тверской гос. унт, 2012. - C. 69-85.

13. Яценко Ю. С. Блоги в учебном процессе [Электронный ресурс]. - Режим доступа : http://internetineflt.narod.ru/MK_1_2.html. 


\title{
ВНУТРЕННЯЯ ОПТИМИЗАЦИЯ УЧИТЕЛЬСКИХ БЛОГОВ, СОЗДАННЫХ НА ВLOGSPOT.СОМ
}

\author{
Скрипка Анна Владимировна \\ кандидат педагогических наук, старший преподаватель кафедры теории и методики среднего \\ образования \\ Коммунальное учреждение «Кировоградский областной институт последипломного педагогического \\ образования имени Василия Сухомлинского», г. Кировоград, Украина \\ annaskripka3@gmail.com
}

\begin{abstract}
Аннотация. В статье приведены рекомендации для учителей-предметников по внутренней оптимизации блога, созданного средствами ресурса blogspot.com: оптимизация URL-адреса блога; корректная формулировка заголовков сообщений или страниц; изъятие повторяющегося контента; добавления метатегов; использование тегов заголовков непосредственно в сообщениях блога. Практическое использование указанных приемов внутренней оптимизации показало, что учительский блог попадает на первые места поисковых серверов, а, следовательно, приобретает свою популярность и дает возможность увеличить посещаемость блога. Указанная проблема приобретает популярность и является значимой, поскольку все большее количество педагогов создают свои блоги и используют их для общения с другими участниками учебно-воспитательного процесса.
\end{abstract}

Ключевые слова: оптимизация; блог учителя; популяризация блога; внутренняя оптимизация блога.

\section{INTERNAL OPTIMIZATION OF TEACHERS' BLOGS CREATED ON BLOGSPOT.COM}

\author{
Hanna V. Skrypka \\ $\mathrm{PhD}$ (pedagogical sciences), senior lecturer in theory and methodology of secondary education \\ Kirovohrad Regional Institute of Postgraduate Pedagogical Education named after V. O. Sukhomlynsky, \\ Kirovohrad, Ukraine \\ annaskripka3@gmail.com
}

\begin{abstract}
The article presents the guidelines for subject teachers on internal optimization of blogs, created by the resource blogspot.com: URL- blog page addresses optimization; correct formulation of posts headers or pages; removal of repetitive content; adding metatags; use header tags directly into blog posts. Practical use of these internal optimization techniques has shown that the teacher's blog takes the first place at search engines, and thus acquires its popularity, makes it possible to increase number of blog's visitors. This issue is gaining popularity and becomes significant because more and more teachers create their own blogs and use them to communicate with other participants of the educational process.
\end{abstract}

Keywords: optimization; teacher's blog; popularization of blog; blog's internal optimization.

\section{REFERENCES (TRANSLATED AND TRANSLITERATED)}

1. Balyk N. R., Lialyk O. O. Active learning with Web 2.0 technologies: Navch. pos. - Ternopil: Navchalna knyha - Bohdan, 2009. - 88 p. (in Ukrainian).

2. Vinnytska N. M., Stelmashchuk S. A. Possibilities of educational blogs. Web 2.0 technology. Informatyka v shkoli : Vydavnycha hrupa «Osnova». - 2012. - \# 7 (43). - 80 p. (in Ukrainian).

3. Dementiievska N. P. Social Services Web 2.0 as an interactive learning tool. [online] / N. P. Dementiievska $\quad-\quad$ Available $\quad$ from http://lib.iitta.gov.ua/652/1/\%D0\%A1\%D0\%BE\%D1\%86\%D1\%96\%D0\%B0\%D0\%BB\%D1\%8C\%D0\% BD\%D1\%96_\%D1\%81\%D0\%B5\%D1\%80\%D0\%B2\%D1\%96\%D1\%81\%D0\%B8_\%D0\%92\%D0\%B5 $\%$ D0\%B1_2.0_1_\%5BCompatibility_Mode\%5D.pdf (in Ukrainian).

4. Zabarna A. P. Using Network diaries (blogs) in the educational process of the school // Informatics and Information Technology in schools. - 2008. - \#5 (17). - p.45-49. (in Ukrainian) 
5. Labudko S.P. Blog as a modern means of interaction teachers [online] / S. P. Labudko. - Available from : http://conf.vntu.edu.ua/eiron/2013/pdf/18.pdf (in Ukrainian).

6. Skrypka Gh. V. Training program Intel «Innovative E-learning model "1 to 1" as a factor in the development of ICT-competence of teachers / Gh. V. Skrypka // Informatics and Information Technology in schools. - 2013. - \#5 (46). - P. 43-47 (in Ukrainian).

7. Sokol I. M. Tekhnologhija VEB 2.0. Web 2.0 technology. Websites, blogs, Services photo, mind maps / Sokol I. M. - K. : Shkiljnyj svit, 2011. - 128 p. (in Ukrainian).

8. Soroko N. V. Using Web technologies in professional work of teachers of philology [online] / N. V. Soroko. - $\quad$ Available from $:$ http://www.irbis-nbuv.gov.ua/cgibin/irbis_nbuv/cgiirbis_64.exe?C21COM=2\&I21DBN=UJRN\&P21DBN=UJRN\&IMAGE_FILE_DOW NLOAD=1\&Image_file_name=PDF/komp_2014_1_9.pdf (in Ukrainian).

9. About Blogger and Search Engine Optimization [online]. - Available from : https://support.google.com/blogger/answer/2472665?hl=ru (in Russian).

10. Search engine optimization [online]. $\quad-\quad$ Available from : http://uk.wikipedia.org/wiki/\%D0\%9E\%D0\%BF\%D1\%82\%D0\%B8\%D0\%BC\%D1\%96\%D0\%B7\%D0 \%B0\%D1\%86\%D1\%96\%D1\%8F_\%D0\%B4\%D0\%BB\%D1\%8F_\%D0\%BF\%D0\%BE\%D1\%88\%D1\%8 3\%D0\%BA\%D0\%BE\%D0\%B2\%D0\%B8\%D1\%85_\%D1\%81\%D0\%B8\%D1\%81\%D1\%82\%D0\%B5\% $\mathrm{D} 0 \% \mathrm{BC}$ (in Ukrainian).

11. Osadchyi V. V. Prerequisites and technology of educational Internet resources / Problemy inzhenernopedahohichnoi osvity. - 2009. - \# 22-23. - P. 162-170 (in Russian).

12. Palkova A. V. Use of Web 2.0 services in the teaching of foreign languages / A. V. Palkova // Prepodavanie inostrannyh jazykov v mul'timedijnom prostranstve. - Tver' : Tverskoj gos. un-t, 2012. - P. 69-85 (in Russian).

13. Jacenko Ju. S. Blogs in the educational process [online]. - Available from : http://internetineflt.narod.ru/MK_1_2.html (in Russian).

\section{(cc) $\mathrm{BY}-\mathrm{NC}-\mathrm{SA}$}

This work is licensed under Creative Commons Attribution-NonCommercial-ShareAlike 4.0 International License. 